\title{
Anti-nociceptive and Antipyretic Activities of Hydroalcoholic Extract of Cassia sophera Linn. Leaves
}

\author{
Debasish Roy ${ }^{1}$, Manik Chandra Shill, Shrabanti Dev ${ }^{1}$, Debashish Deb ${ }^{2}$, Masum Shahriar ${ }^{3}$, \\ Asish Kumar Das ${ }^{1}$ and M. Shahabuddin Kabir Choudhuri ${ }^{3}$ \\ ${ }^{1}$ Pharmacy Discipline, Khulna University, Khulna, Bangladesh \\ ${ }^{2}$ Biotechnology and Genetic Engineering Discipline, Khulna University, Khulna, Bangladesh \\ ${ }^{3}$ Department of Pharmacy, Jahangirnagar University, Savar, Dhaka, Bangladesh
}

\begin{abstract}
The crude hydroalcoholic extract of Cassia sophera Linn. leaves were investigated for its possible analgesic and antipyretic activities in rodents. The peripheral analgesic activity of $C$. sophera leaves was studied using acetic acidinduced writhing in mice and central analgesic activity was evaluated by using heat-induced pain in mice. The antipyretic activity of HECS was studied in Brewer's yeast-induced pyrexia in rats. All these experiments were done at the doses of 300 and $600 \mathrm{mg} / \mathrm{kg}$ body weight. Intraperitoneal administration of $C$. sophera hydroalcoholic extract (HECS) produced significant $(\mathrm{P}<0.01)$ reduction in number of writhing induced by acetic-acid. Moreover, in hotplate test, HECS significantly $(\mathrm{P}<0.01)$ raised the pain threshold at different time of observation $(0-180 \mathrm{~min})$ in comparison with control. The extract also showed significant as well as dose-dependent antipyretic activity in Brewer's yeast-induced pyrexia in rats throughout the observation period of $4 \mathrm{~h}$.
\end{abstract}

Key words: Cassia sophera; Analgesic; Antipyretic.

\section{Introduction}

Cassia sophera L. is a medicinal plant belonging to the family Caesalpiniaceae. As a medicinal plant it is very popular among the traditional medicine practitioners of Bangladesh and India. Locally the plant is known as Kasunda and in Homeopathy it is used as a potent remedy from plant kingdom for allergic rhinitis, asthma and osteoarthritis. Even ethnobotanical literature refers it to be effective in treating acute bronchitis, cough pityriasis, psoriasis, asthma, diabetes and convulsions of children (Dutt, 1995; Drury, 1873; Agharkar, 1991; Chopra, 1956; Kirtikar et al, 2000; Nadkarni, 1982; Dymock et al, 1890). Traditionally the plant is also used for treating microbial infections, remedy of fever and also against fungal infections (Ghani, 1998). Its leaves have free radical scavenging activity (Rahman et al., 2008). Leaves of C. sophera also reported to have anti-insecticidal activity (Kestenholz, 2007). Its seeds can be used for a wide range of therapeutic purpose as analgesic, sedative and anticonvulsant agent (Bilal et al., 2007). Despite the ethno-medicinal properties attributed to $C$. sophera very little pharmacological information about this plant has been reported to the best of our knowledge. Thus, we decided to evaluate the analgesic, anti-inflammatory and antipyretic effect of the HECS obtained from the leaves of Cassia sophera L., by using classical pharmacological assays for the purpose of validating its ethnomedical use.

\section{Materials and Methods}

Plant materials collection and extraction: C. sophera leaves were collected from different places of Jhikargacha upzilla, Dist-Jessore, Division-Khulna, Bangladesh, in February, 2008. The plant was taxonomically identified by the experts of Bangladesh National Herbarium, Mirpur, Dhaka and a voucher specimen (accession no. DACB32099) was also deposited there. Leaves were shed dried and powdered with a suitable grinder. The powdered material was cold extracted in flat-bottomed glass container using $70 \%$ ethanol for 15 days at room temperature. The extract was filtered through Whatman filter paper number 1 and remaining portion of the extract was re-extracted for 7 days. The filtrate (ethanol extract) was dried using a rotary evaporator followed by freeze drier.

Animals: Swiss albino mice (male), weighting 23-25 g and wister rats of either sex weighing 180-200 $\mathrm{g}$ bred in the Animal House of the Department of Pharmacy, Jahangirnagar University, Savar, Dhaka, Bangladesh were

Correspondence to: MSK Choudhuri, E-mail address: mskchoudhuri@yahoo.com 
used for the present experiments. All the animals were acclimatized for one week prior to the experiments. The animals were housed under standard laboratory conditions (relative humidity $55-65 \%$, temperature $25.0 \pm 2^{\circ} \mathrm{C}$, and $12 \mathrm{~h}$ light dark cycle). The animals were fed with standard diet from International Center for Diarrheal Diseases and Research, Bangladesh (ICDDR, B) and had free access to tap water.

Drugs: Acetic acid (Sigma chemicals, USA), diclofenac sodium (Square Pharmaceuticals Ltd, Bangladesh), paracetamol (Square Pharmaceuticals Ltd, Bangladesh), nalbuphine (Incepta Pharmaceuticals Ltd.) were collected from the mentioned sources. All other chemicals were analytical grade.

Anti-nociceptive activity of HECS: Anti-nociceptive activity was assessed by abdominal writhing test using acetic acid and hot plate reaction time applied to male albino mice. Animals of the negative control received the vehicle only ( $1 \%$ Tween $80,10 \mathrm{ml} / \mathrm{kg}$, i.p).

Acetic acid-induced writhing assay: Anti-nociceptive activity of $C$. sophera was tested using the acetic acidinduced writhing method as described by Ahmed et al., (2004) with minor modifications. In the writhing test, $0.6 \%$ acetic acid $(10 \mathrm{mg} / \mathrm{kg}$, i.p.) was injected and the number of writhes were counted for a period of $10 \mathrm{~min}$. Diclofenac sodium $(10 \mathrm{mg} / \mathrm{kg}$, i.p.) or the C. sophera leaf extract (HECS, 300 and $600 \mathrm{mg} / \mathrm{kg}$ ) were administered intraperitoneally $30 \mathrm{~min}$ before acetic acid injection.

Hot plate reaction time assay: The hot plate method was used to measure analgesic activity as described by Shanmugasundaram and Venkataraman (2005) with minor modifications. The temperature of the metal surface was maintained at $55 \pm 0.2^{\circ} \mathrm{C}$. Latency to a discomfort reaction (licking, shaking or jumping) was determined before and after drug administration. The cut-off time was fixed to $15 \mathrm{~s}$ to avoid the damage to the paw of the animals (Hasan et al., 2009). The latency was recorded at $0,30,60,120$, 180 min following i.p. administration of the agents. The prolongation of the latency times compared with the values of the control was used for statistical comparison.

Antipyretic activity of HECS: The antipyretic activity of HECS was evaluated using Brewer's yeast-induced pyrexia in rats as described by Loux et al., (1972) with minor modifications. Pyrexia was induced by subcutaneously injecting $20 \% \mathrm{w} / \mathrm{v}$ Brewer's yeast suspension $(10 \mathrm{ml} / \mathrm{kg})$. Seventeen hrs after the injection, the rectal temperature of each rat was measured using a thermometer. Only rats that showed an increase in temperature of at least $0.7{ }^{\circ} \mathrm{C}$ were employed for the experiments. Prior to the experiment, the rats were maintained in separate cages for 7 days and the animals with approximately constant rectal temperature were selected for the study. Paracetamol $(200 \mathrm{mg} / \mathrm{kg}$, p.o.) was used as standard drug for comparing the antipyretic action of HECS.

Statistical analysis: Student's t-test was used to determine a significant difference between the control group and experimental groups. Experimental values were expressed as Mean \pm SEM (Standard Error of Mean). $\mathrm{P}<$ 0.05 was considered as significant.

\section{Results}

\section{Antinociceptive activity}

Writhing assay: The HECS leaves produced significant writhing inhibition on acetic acid-induced writhing mice. The extract produced about $20.90 \%$ and $42.47 \%$ inhibition of writhing at the doses of 300 and 600 $\mathrm{mg} / \mathrm{kg}$ body weight respectively, which was comparable to that of standard drug diclofenac sodium where the inhibition was about $61.41 \%(\mathrm{p}<0.05)$ at the dose of 10 $\mathrm{mg} / \mathrm{kg}$ body weight respectively (Table 1 ).

Table 1. Effect of hydroalcoholic extract of the leaf of Cassia sophera on acetic acid induced writhing in mice

\begin{tabular}{lccc}
\hline Groups & $\begin{array}{c}\text { Dose } \\
(\mathrm{mg} / \mathrm{kg})\end{array}$ & $\begin{array}{c}\text { Number of } \\
\text { writhing }\end{array}$ & $\begin{array}{c}\text { Inhibition } \\
(\%)\end{array}$ \\
\hline Control & 10 & $25.5 \pm 1.41$ & \\
$\begin{array}{l}\text { Standard drug } \\
\text { (Diclofenac }\end{array}$ & & & \\
sodium) & 10 & $9.84 \pm 0.72$ & $61.41^{* *}$ \\
HECS & 300 & $20.17 \pm 1.14$ & $20.90^{*}$ \\
HECS & 600 & $14.67 \pm 0.87$ & $42.47^{* *}$ \\
\hline
\end{tabular}

All administrations were made intraperitonealy. Values expressed as mean \pm SEM, $(\mathrm{n}=6) ; * *: \mathrm{p}<0.01, *: \mathrm{p}<0.05$ significant compared to control.

Hot plate method: HECS when intraperitoneally administered with a dose of 300 and $600 \mathrm{mg} / \mathrm{kg}$ in mice has shown significant analgesic activity in hot plate method as supported by increase in latency time. The increase in latency time was dose dependant. Both doses of the extract showed significant analgesic activity; however, it was the maximum for the dose of $600 \mathrm{mg} / \mathrm{kg}$ and this was comparable with standard (Table 2). 
Table 2. Effect of hydroalcoholic extract of Cassia sophera leaves on the latency of mice exposed to hot plate

\begin{tabular}{|c|c|c|c|c|c|c|c|c|c|c|}
\hline \multirow[t]{2}{*}{ Group } & \multirow{2}{*}{$\begin{array}{c}\text { Dose } \\
\mathrm{mg} / \mathrm{kg}\end{array}$} & \multicolumn{5}{|c|}{ Mean latency period before and after drug administration } & \multicolumn{4}{|c|}{ Percentage of inhibition } \\
\hline & & $0 \mathrm{~min}$ & $30 \mathrm{~min}$ & $60 \min$ & $120 \mathrm{~min}$ & $180 \min$ & $30 \mathrm{~min}$ & $60 \mathrm{~min}$ & $120 \mathrm{~min}$ & $180 \mathrm{~min}$ \\
\hline Control & 10 & $3.18 \pm 0.17$ & $3.21 \pm 0.42$ & $3.16 \pm 0.5$ & $3.06 \pm 0.44$ & $2.98 \pm 0.56$ & & & & \\
\hline Standard & 10 & $3.12 \pm 0.06$ & $5.51 \pm 0.48$ & $7.95 \pm 1.16$ & $11.19 \pm 1.38$ & $12.38 \pm 1.56$ & 43.38 & 60.76 & 72.13 & 74.79 \\
\hline Dose1 & 300 & $3.19 \pm 0.08$ & $4.10 \pm 0.25$ & $4.71 \pm 0.28$ & $5.1 \pm 0.41$ & $5.36 \pm 0.39$ & 22.21 & 32.32 & 37.52 & 40.58 \\
\hline Dose2 & 600 & $3.17 \pm 0.10$ & $4.81 \pm 0.32$ & $6.12 \pm 0.42$ & $7.05 \pm 0.43$ & $7.88 \pm 0.61$ & 34.25 & 48.31 & 55.12 & 59.85 \\
\hline
\end{tabular}

All administrations were made intraperitonealy. Values represented as mean $\pm \mathrm{SEM},(\mathrm{n}=6){ }^{*}: \mathrm{P}<0.05, * *: \mathrm{P}<0.01$, significant compared to control.

Antipyretic activity: This study was performed on yeast-induced pyrexia in rats. HECS significantly reversed hyperthermia at either dose $(300 \mathrm{mg} / \mathrm{kg}$ and $600 \mathrm{mg} / \mathrm{kg})$. Time of peak effect was obtained between 1 to $4 \mathrm{~h}$ after oral administration. The standard drug, Paracetamol (200 $\mathrm{mg} / \mathrm{kg}$ ) also suppressed hyperthermia induced by yeast significantly $(\mathrm{P}<0.01)$ during all the observation times when compared with control values (Table 3 ).

Table 3. The antipyretic effect of the hydroalcoholic extract of Cassia sophera leaves

\begin{tabular}{ccccccc}
\hline \multirow{2}{*}{ Groups } & \multirow{2}{*}{ Dose $(\mathrm{mg} / \mathrm{kg})$} & \multicolumn{5}{c}{ Average rectal temperature $\left({ }^{0} \mathrm{C}\right)$} \\
\cline { 3 - 6 } & & $0 \mathrm{hr}$ & $1 \mathrm{hr}$ & $2 \mathrm{hr}$ & $3 \mathrm{hr}$ & $4 \mathrm{hr}$ \\
\hline Control & 10 & $36.95 \pm 0.2$ & $38.07 \pm 0.32$ & $38.47 \pm 0.28$ & $38.46 \pm 0.22$ & $38.57 \pm 0.3$ \\
Paracetamol & 200 & $37.15 \pm 0.25$ & $35.87 \pm 0.17^{* *}$ & $35.84 \pm 0.24^{* *}$ & $35.88 \pm 0.28^{\star *}$ & $35.93 \pm 0.26^{\star \star}$ \\
HECS & 300 & $37.01 \pm 0.21$ & $36.82 \pm 0.11^{*}$ & $36.8 \pm 0.41^{\star *}$ & $36.74 \pm 0.45^{\star *}$ & $36.79 \pm 0.38^{\star}$ \\
HECS & 600 & $37.08 \pm 0.1$ & $36.4 \pm 0.41^{*}$ & $36.23 \pm 0.56^{\star *}$ & $36.37 \pm 0.55^{\star *}$ & $36.38 \pm 0.44^{\star *}$ \\
\hline
\end{tabular}

Values are expressed as mean \pm S.E.M; (no. of animal $\mathrm{n}=6$ ). ${ }^{* *}: \mathrm{p}<0.01,{ }^{*}: \mathrm{p}<0.05$ significant compared to control.

\section{Discussion}

Pain can be distinguished as two types, peripheral or neurogenic pain which may involve the following pathological states: peripheral nociceptive afferent neurons which are activated by noxious stimuli and central mechanism which is activated by afferent inputs pain sensation (Rang et al., 2011). Here the antinociceptive activity of HECS was tested by both acetic acid-induced writhing in mice and hot plate method where hot plate method was considered to be selective for screening of the compound acting through the opoid receptor and acetic acid-induced writhing assay is useful in detecting both central as well as peripheral analgesics (Mate et al., 2008). Acetic acid-induced writhing model represents pain sensation by triggering localized inflammatory response. It induces algesia by liberation of endogenous substances, which in turn excite the pain nerve endings (Taesotikul et al., 2003). Increased levels of $\mathrm{PGE}_{2}$ and $\mathrm{PGF}_{2 \alpha}$ in the peritoneal fluid have been reported to be responsible for pain sensation caused by intraperitoneal administration of acetic acid (Derardt et al., 1980). The hydroalcoholic extract of C. sophera leaves showed statistically significant inhibition on acetic acid-induced writhing in mice. Therefore, the possible mechanism behind the analgesic effect of HECS may be the inhibition of synthesis or action of prostaglandin. Generally the centrally acting analgesics elevate the pain threshold of mice towards heat. Here, in hot plate method, HECS increased the mean basal latency which shows that the extract also acts like centrally acting analgesics. Narcotic analgesic inhibits both the types of pain, while NSAIDS such as paracetamol and aspirin inhibit only the peripheral pain (Elisabetsky et al., 1995; Pal et al., 1999). HECS has inhibited both types of pain which suggests that the extract may act as a narcotic analgesic. Alkaloids, glycosides and tannins have been reported for analgesic activity (Deb et al., 2010; Starec et al., 1988). Phytochemical analysis reveals that the leaf extract of $C$. sophera contains alkaloid, steroid, tannin, and reducing sugar (Roy et al., 2010).

Most of the anti-inflammatory and analgesic drugs show antipyretic activity. In this context, the HECS was also tested for possible antipyretic activity in Brewer's yeast-induced febrile rat model. Infection or one of the sequele of tissue damage, inflammation, graft rejection, or other disease states can cause fever. Antipyretic agents 
reduce the elevated body temperature. Body temperature can be raised due to several other normal reasons like exercise or increase in ambient temperature. But a standard antipyretic drug like paracetamol does not influence body temperature in such cases (Paschapur et al., 2009). Yeast-induced fever is a pathogenic fever. Its etiology includes production of prostaglandins, which set the thermoregulatory center at a lower temperature (Bentley et al., 1983; Chandrasekharan et al., 2002). The present result shows that HECS possesses significant as well as dose dependent antipyretic effect in yeast-induced pyrexia which is comparable to that of the standard antipyretic drug paracetamol. Suppression of prostaglandin as do paracetamol may be the possible means of antipyretic effect of HECS though many others mediators or processes can be the reason for the pathogenesis of fever.

Based on the results of the present studies, it can be concluded that the hydroalcoholic extract of $C$. sophera leaves possesses significant analgesic and antipyretic potential. However, further detail studies are essential to find out the underlying mechanisms and also to isolate the active compound(s) responsible for these pharmacological properties.

\section{References}

Agharkar, S.P. 1991. Medicinal Plants of Bombay Presidency, Scientific Publishers, Jodhpur, p. 58.

Ahmed, F., Selim M.S.T., Das A.K. and Choudhuri M.S.K. 2004. Anti-inflammatory and analgesic activities of Lipia nodiaflora Linn. Pharmazie, 59, 329-30.

Bentley, G.A., Newton S.H. and Starr J. 1983. Studies on the Anti-nociceptive Action of Agonist Drugs and their Interaction with Opioid Mechanisms. Br. J. Pharmacol., 79, $125-34$.

Bilal, A., Khan N.A., Ghufran V. and Inamuddin 2005. Pharmacological investigation of Cassia sophera Linn. Var. purpurea, roxb. Medical J. of Islamic World Academy of Sci., 15, 105-09.

Chandrasekharan, N.V., Dai, H., Roos, K.L.T., Evanson, N.K., Tomsik, J., Elton, T.S. and Simmons, D.L. 2002. COX-3, a cyclooxygenase-1 variant inhibited by acetaminophen and other analgesic/antipyretic drugs: cloning structure and expression. Proc. Natl. Acad. Sci., 99, 13926-31.

Chopra, R.N., Nayar, S.L. and Chopra, I.C. 1956. Glossary of Indian Medicinal Plants, CSIR, New Delhi, p. 55.
Deb, D., Dev S., Das, A.K., Khanam, D., Banu, H., Shahriar, M., Ashraf, A. and Choudhuri, M.S.K. 2010. Anti-nociceptive, anti-inflammatory and anti-diarrheal activity of crude root extract of Lasia spinosa Linn. (Family- Araceae). Lat. Am. J. Pharm., 29, 1269-1276.

Derardt, R., Jougney, S., Delevalcee, F. and Falhout, M. 1980. Release of prostaglandins $\mathrm{E}$ and $\mathrm{F}$ in an algogenic reaction and its inhibition. Eur. J. Pharmacol., 51, 17-24.

Drury, H. 1873. Useful Plants of India, William H Allen and Co. London, pp. 122-23.

Dutt, U.C. 1995. The Materia Medica of the Hindus, Mittal Publications, New Delhi, pp. 156-57.

Dymock, W., Warden, C.J.H. and Hooper, D. 1890. Pharmacographica Indica, Trubner and Co, Ltd., London, II, 520-23.

Elisabetsky, E., Amador, T.A., Albuquerque, R.R., Nunes, D.S. and Carvalho, A.C. 1995. Analgesic activity of Psychotria colorata (Willd. ex R. and S.) Muell. Arg. alkaloids. J Ethnopharmacol., 48, 77 - 83.

Ghani, A. 1998. Medicinal Plants of Bangladesh, Asiatic Society, $1^{\text {st }}$ edn. p. 37.

Hasan, S.M.R., Jamila, M., Majumder, M.M., Akter, R., Hossain, M.M., Mazumder, M.E.H., Alam, M.A., Jahangir, R., Rana, M.S., Arif, M. and Rahman, S. 2009. Analgesic and antioxidant activity of hydromethanolic extract of Mikania scandens (L.) willd. leaves. Am. J. Pharmacol. Toxicol., 4, 1-7.

Kestenholz, C., Stevenson, P.C. and Belmain, S.R. 2007. Comparative study of field and laboratory evaluations of the ethnobotanical Cassia sophera L. (Leguminosae) for bioactivity against the storage pests Callosobruchus maculatus (F.) (Coleoptera: Bruchidae) and Sitophilus oryzae (L.) (Coleoptera: Curculionidae). J. Stored Prod. Res., 43, 79-86.

Kirtikar, K.R. and Basu, B.D. 2000. Indian Medicinal Plants, Sri Satguru Publications, Delhi, IV, 1207-10.

Loux, J.J., Palma, P.D.D. and Yankell, S.L. 1972. Antipyretic testing of aspirin in rats. Toxicol. Appl. Pharmacol., 22, 672-75.

Mate, G.S., Naikwade, N.S., Magdum, C.S., Chowki, A.A. and Patil, S.B. 2008. Evaluation of anti-nociceptive activity of Cissus quadrangularis on albino mice. Int. J. Green Pharmacy, 118-21.

Nadkarni, K.M. 1982. Indian Materia Medica, Popular Parkashan Pvt Ltd., Bombay, I, 290-91.

Pal, S., Sen, T. and Chaudhuri, A.K. 1999 Neuropsychopharmacological profile of the methanolic fraction of Bryophyllum pinnatum leaf extract. J Pharma Pharmacol., 51, 313. 
Paschapur, M.S., Patil, S., Patil, S.R., Kumar, R. and Patil, M.B. 2009. Evaluation of the analgesic and antipyretic activities of ethanolic extract of male flowers (inflorescences) of Borassus flabellifer L. (Arecaceae). Int. J. Ph. Sci., 1.

Rahman, A., Rahman, M.M., Sheik, M.M.I., Rahman, M.M., Shadli, S.M. and Alam, M.F. 2008. Free radical scavenging activity and phenolic content of Cassia sophera L. African J. of Biotechnol., 7, 1591-93.

Rang, H.P., Dale, M.M., Ritter, J.M., Moore, P.K. 2005. Pharmacology. $5^{\text {th }}$ edn. New Delhi: Churchill Livingstone Publ, p. 562.
Roy, D., Shill, M.C., Dev, S., Deb, D. and Das, A.K. 2010. Phytochemical and Toxicological Assay of Leaf of Cassia sophera Linn. Pharmacology online, 1, 365-74.

Shanmugasundaram, P. and Venkataraman, S. 2005. Antinociceptive activity of Hygrophilous auriculata (schum) heine. Afr. J. Trad. CAM, 2, 62- 69.

Starec, M., Waitzov'a, D. and Elis, J. 1988. Evaluation of the analgesic effect of RG-tannin using the "hot plate" and "tail flick" method in mice. Cesk Farm, 37, 319-21.

Taesotikul, T., Panthong, A., Kanjanapothi, D., Verpoorte, R. and Scheffer, J.J.C. 2003. Anti-inflammatory, antipyretic and antinociceptive activities of Tabernaemontana pandacaqui Poir. J. Ethnopharmacol., 84, 31-35. 